\title{
A Study on Differential Characteristics of HSC Containing RHA and M-Sand as an Aggressive Environment
}

\author{
S. Swarna Manjula1 ${ }^{1}$ R. Surya Prakash ${ }^{2}$ \\ ${ }^{1}$ Assistant Professor, Department of Civil Engineering, Sir Vishveshwaraiah Institute of Science \& Technology, \\ Andhra Pradesh, India \\ ${ }^{2}$ Department of Civil Engineering, Sir Vishveshwaraiah Institute of Science \& Technology, Andhra Pradesh, \\ India
}

\section{Article Info}

Volume 8, Issue 6

Page Number : 365-371

\section{Publication Issue}

November-December-2021

\section{Article History}

Accepted : 01 Dec 2021

Published : 12 Dec 2021

\section{ABSTRACT}

Concrete is a versatile material and can be extended to applications requiring to perform in aggressive environments. In these environments, concrete should be highly durable for longer service life. The present thesis is an effort directed towards the achieving high performance in concrete by using RHA as supplementary cementitious material. To achieve high Strength in the concrete, it is necessary to have better understanding of the behavior of constituent materials. Thus, the behavior of RHA in concrete in terms of efficiency was assessed through the results available from literature. A mix design method was suggested and a wide range of concretes varying from $85-87 \mathrm{Mpa}$ with replacement levels varying from 0 to 15 Percentage were attempted. These concretes could be produced with the mixing, compaction, curing procedures conventionally used and with the available RHA. A maximum strength of about 86Mpa was obtained which compares well or was even better with the results reported hitherto in literature.

Keywords : RHA, Aggressive Environment, M-Sand

\section{INTRODUCTION}

Rice Husk Ash (RHA) is one such pozzolanic material, which can be used as a cementitious ingredient in cement composites and is also considered to be an effective material for applications related to marine environment. RHA is obtained by the controlled combustion of the rice husk, which is an agricultural by product. Research work to date suggest that this supplementary cementitious material improves many characteristics of the concrete such as strength, workability, permeability and durability and it was suggested that it could be used in two ways, either as an additive or as a replacement material. By a proper proportioning, and a judicial choice of the replacement percentage (as per the need) one can produce RHA concretes of excellent durability. However, as yet there is no specific methodology available for designing concretes incorporating RHA based on even the strength characteristics. Thus in the present investigation, it was felt necessary to evaluate the reactivity/efficiency of RHA, suggest an approach for incorporation of RHA into concrete and lastly, to evaluate the durability and corrosion 
resistance, so that they can be adopted for structural applications with greater confidence. It is proposed to make the above investigations reasonably comprehensive with the overall objective of achieving high performance in the concrete composites produced.

\subsection{HIGH STRENGTH CONCRETE (HSC)}

High-strength concrete structures can hold more weight and therefore be made slimmer than normal strength concrete columns, which allows for more useable space, especially in the lower floors of buildings. High-strength concrete is specified where reduced weight is important or where architectural considerations call 2 for small support elements. By carrying loads more efficiently than normal-strength concrete, high-strength concrete also reduces the total amount of material placed and lower the overall cost of the structure.

\section{$1.2 \quad$ 1.2. AIM}

In this chapter the production of RHA, and its usage, chemical and physical characteristics were briefly discussed. Also, a brief review of the information available on the strength, durability and corrosion behavior of RHA in concrete was presented. 3 The overall discussions earlier show that a comprehensive investigation into the different parameters influencing the behavior of RHA in concrete is essential. The main aims of the present investigations can be given as follows. 1. For better understanding of the pozzolanic reactivity of RHA, it is proposed to evaluate the efficiency or reactivity of RHA in concretes from the data available in literature. 2. Based on these efficiencies, it is proposed to have a mix design methodology to incorporate

RHA in to concrete to achieve concretes of specified strength. 3. Further, it is proposed to carry out experimental investigations on concretes over a wide range of strength and the required percentage replacement levels required to verify the effectiveness of the proposed methodology in achieving the specified strength. 4. The performance of these welldesigned concretes was to be assessed for their durability in aggressive environments.

\subsection{SCOPE}

Though the aim is to have a comprehensive investigation, it is essential to limit the scope as presented below, so that the results are of practical significance. In the present investigation concretes over wide range of strengths (varying from around $90 \mathrm{Mpa}$ ) and at replacement levels varying only between $0-15 \%$ were attempted. Only conventional mixing, compaction and curing methods were adopted to produce these concretes. The assessment of durability of these concretes were studies.

\section{REVIEW OF LITERATURE}

\subsection{Overview}

Rice husk ash is a material having a very high pozzolanic reactivity, is produced through the calcination of rice husk. Mehta (1994) reported that RHA can be produced by maintaining the husk combustion temperature at 500 to $700^{\circ} \mathrm{C}$ for relatively long periods (until most of the carbon is removed by oxidation). Alternatively, ash samples with similar characteristics were produced at temperatures as high as $700-800^{\circ} \mathrm{C}$, provided the high-temperature exposure was limited to less than one minute. James and Rao (1986) reported the results of a comprehensive study on the effect of burning conditions of rice husk on the physical characteristics and chemical activity of the ash produced. Ash samples were prepared by heating the husk at 300 , $400,500,600,700,800$ and $900^{\circ} \mathrm{C}$, for time periods ranging from $1-30 \mathrm{~h}$. The 5 minimum thermal treatment to obtain carbon-free ash was $400^{\circ} \mathrm{C}$ for 12 hours. However, the product showed $3 \%$ loss on ignition due to the presence of hydroxyl water ( $\mathrm{Si}$ $\mathrm{OH})$. Irrespective of the duration of heating, 
crystallization of silica did not take place below $700^{\circ} \mathrm{C}$. The silica in the $800^{\circ} \mathrm{C}$ sample was slightly crystalline, however all the $900^{\circ} \mathrm{C}$ samples contained crystalline silica.

\subsection{ADVANTAGES OF RHA}

The proportioning of concrete involves a fine balance between economy and the requirements for workability, strength, durability, density and appearance. RHA 7 as a Pozzolanic material has some advantages and disadvantages which were reported by various researchers like Mehta (1994); Sandberg (1995); Nehdi et al. (2003) as mentioned below

- Highly reactive material.

- Accelerates initial cement hydration.

- It rapidly consumes the hydrated lime produced by cement hydration to produce additional cementitious reaction products.

- High surface area approximately $20,000 \mathrm{~m} 2 / \mathrm{kg}$.

- It is also a filler material and results in increased long-term strength development.

- It gives significantly enhanced early strength.

- Reduces the early heat of hydration.

- Helps in the production of high strength and low permeability concrete with enhanced durability.

\subsection{METHODOLOGY}

$>$ Replacement of cement with Rice husk ash in Respective ratio.

$>$ High Strength concrete in which cement was replaced with $0 \%, 5 \%, 10 \%$ and $15 \%$ of Rice husk ash

> Fine aggregate is replaced with $100 \%$ Manufacturing Sand.

\section{MIXING, COMPACTION AND CURING}

Good concrete could be obtained only through uniform and thorough mixing, better compaction and adequate curing. In the laboratory the concrete was mixed in a pan mixer of 40 liters capacity. The mixing time was kept in general to about 3 to 417 minutes both for normal and RHA concretes, where higher percentages of superplasticizer were used the mixing time was increased to about 5 to 6 minutes to utilize the complete potential of the superplasticizer. After mixing, the workability is measured by slump test. The cube and cylindrical specimens used for the various investigations on concrete were compacted using a $25 \mathrm{~mm}$ diameter needle vibrator. The compaction was continued till the entrapped air comes out of the mould so that the concrete is uniform. After casting, the specimens were subjected to moist curing with a wet gunny bag initially. The specimens were demoulded on the next day and immersed in the normal water.

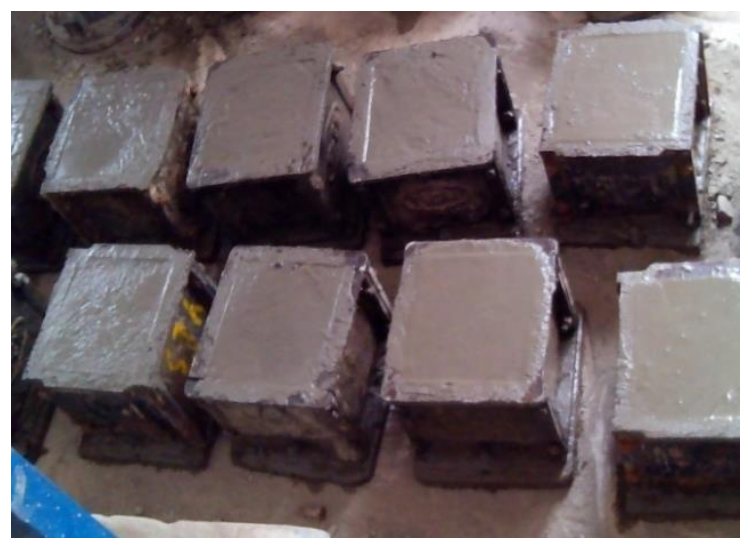

Sampling of concrete

\subsection{MATERIALS AND EXPERIMENTAL STUDYCHEMICAL COMPOSITION OF}

\begin{tabular}{|c|c|c|}
\hline S.NO & Oxide & Present Content \\
\hline 1 & $\mathrm{CaO}$ & 65.49 \\
\hline 2 & $\mathrm{SiO}_{2}$ & 21.67 \\
\hline 3 & $\mathrm{Al}_{2} \mathrm{O}_{3}$ & 5.97 \\
\hline 4 & $\mathrm{Fe}_{2} \mathrm{O}_{3}$ & 3.85 \\
\hline 5 & $\mathrm{SO}_{3}$ & 1.66 \\
\hline 6 & $\mathrm{MgO}$ & 0.78 \\
\hline 7 & $\mathrm{~K} 2 \mathrm{O}$ & 0.46 \\
\hline 8 & $\mathrm{Na}_{2} \mathrm{O}$ & 0.12 \\
\hline
\end{tabular}

CEMENT PHYSICAL PROPERTIES OF OPC 


\begin{tabular}{|c|c|c|c|}
\hline S.No & $\begin{array}{c}\text { Characteristic } \\
\text { of cement }\end{array}$ & Value & $\begin{array}{c}\text { Code } \\
\text { specifications } \\
\text { (IS 4031- } \\
\text { 1988) }\end{array}$ \\
\hline 1 & Fineness of & $\mathbf{8 \%}$ & - \\
\hline 2 & Normal & $\mathbf{2 9 \%}$ & Not specified \\
\hline 3 & Initial setting & $\mathbf{4 0}$ & $>30$ \\
\hline 4 & Final setting & 350 & $<600$ \\
\hline 5 & Specific gravity & 3.15 & - \\
\hline
\end{tabular}

in Table 5.1 and Fig. 5.2 presents the variation of absorption with time different concretes. The initial absorption values (at $30 \mathrm{~min}$.) for all concretes were presented in Table 5.2 which were compared with recommendations given by Concrete Society (CEB, 1989) for 30 minutes.

\subsection{DURABILITY CHARACTERISTICS}

\subsubsection{WATER ABSORPTION}

This study was done to know the relative porosity or permeability characteristics of the concretes and was carried out according to ASTM C 642-82 at 28 days. The specimens used for this test were $100 \mathrm{~mm}$ cube cured in water for 28 days. The concrete cubes were cleaned by light scrubbing to remove any loose material, and the initial weights were taken (w1). The cubes were dried in a hot air oven at 1050C and changes in the weights were measured at regular intervals. This drying was continued until the differences between any two successive weights were less than $0.2 \%$ of the lowest weight obtained. Then the specimens were removed from the oven and were allowed to cool to room temperature naturally without absorbing any moisture.

After this, specimens were immersed in water (with a minimum of $25 \mathrm{~mm}$ water on top), and weights were taken at regular intervals (w2, w3.). This was continued

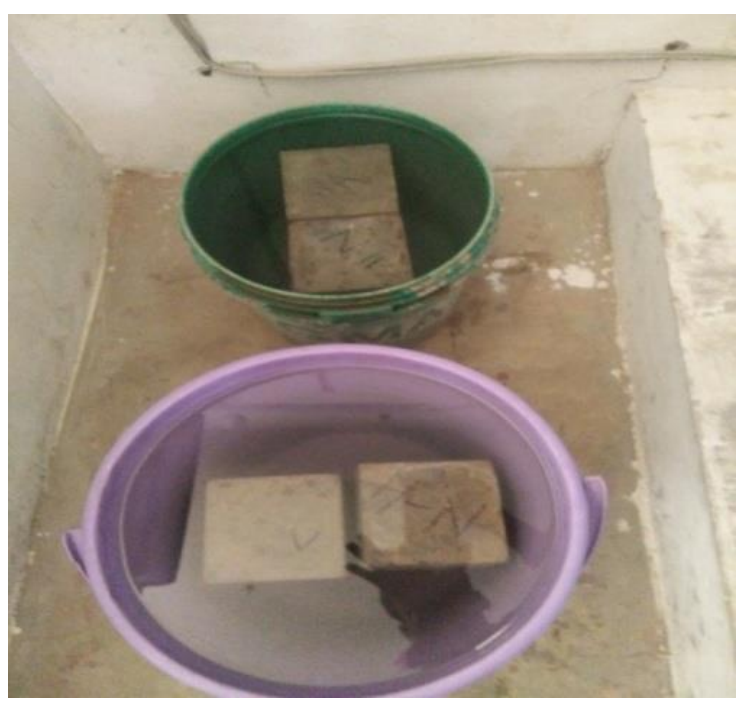

Fig.3.1.1 water absorption

Table 3.1.1 Assessment criteria for absorption (CEB, 1989)

\begin{tabular}{|l|l|l|}
\hline $\begin{array}{l}\text { Absorption } \\
(\% @ 30 \mathrm{~min})\end{array}$ & Absorption rating & Concrete Quali \\
\hline$<3.0$ & Low & Good \\
\hline 3.0 to 5.0 & Average & Average \\
\hline$>5.0$ & High & Poor \\
\hline
\end{tabular}
until the difference between successive weights3.2 ACID ATTACK STUDIES (between the final 12 -hour intervals) was less than $0.2 \%$ Concrete is easily deteriorated by the aggressive of the highest weight (72 hours). The percentageaction of chemical substances which could result in absorption was calculated as follows

Absorption $(\%)=(\mathrm{w} 2-\mathrm{w} 1) / \mathrm{w} 1 \times 100$ the disruption, cracking or dissolution. These Where $\mathrm{w} 1$ = weight of the dried sample after complete drying

$\mathrm{w} 2$ = final weight of the surface dry sample after immersion

The testing of water absorption as shown in fig 5.1. The results of this study for all the concretes were presented aggressive ions particularly sulfate chemically react

\begin{tabular}{|c|c|c|c|c|c|}
\hline \multirow{3}{*}{$\begin{array}{l}\text { SI. } \\
\text { No }\end{array}$} & \multirow{3}{*}{ Name } & \multirow{3}{*}{$\begin{array}{c}\text { Initial } \\
\text { Weight } \\
\text { (gms) }\end{array}$} & \multicolumn{3}{|c|}{$\begin{array}{c}\text { Immersion period } \\
\qquad\left(5 \% \mathrm{H}_{2} \mathrm{SO}_{4}\right)\end{array}$} \\
\hline & & & \multicolumn{3}{|c|}{ Weight loss (\%) } \\
\hline & & & $\begin{array}{c}7 \\
\text { Days }\end{array}$ & $\begin{array}{c}14 \\
\text { Days }\end{array}$ & 28 Days \\
\hline 1 & $\mathrm{CO}$ & 2464 & 0.57 & 0.65 & 5.96 \\
\hline
\end{tabular}

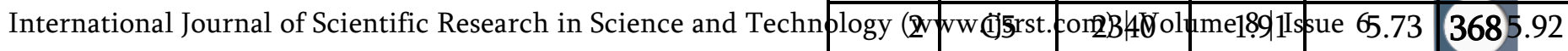

\begin{tabular}{|r|r|r|r|r|r|}
\hline 3 & C10 & 2450 & 0.31 & 0.59 & 12.9 \\
\hline 4 & C15 & 2585 & 8.6 & 10.44 & 10.87 \\
\hline
\end{tabular}


with the hydrated C3A compound present in the concrete and forms ettringite $(3 \mathrm{CaO} \mathrm{Al} 2 \mathrm{O} 33 \mathrm{CaSO} 4$ $32 \mathrm{H} 2 \mathrm{O})$. This ettringite causes considerable expansion and results in cracking. This leads to high maintenance and repair costs. But the process of deterioration of concrete takes a long time. To accelerate this, the acid attack test is adopted to study the deterioration characteristics of these concretes. To perform the acid attack studies, in the present investigation immersion technique was adopted. After 56 days of curing, the $100 \mathrm{~mm}$ cubes used for this test were cleaned properly with nylon brush and water. For each initial cube weight was measured. Then each cube was tied with a numbered plastic token for identification. The specimens were then immersed in the test solution, in present case 3\% $\mathrm{H} 2 \mathrm{SO}$, in a plastic tub (when the solution was at room temperature). The specimens were arranged in the solution in such a way that all the faces of the cube were exposed to the solution as mentioned in the ASTM-C452-82. The ratio of specimen volume to solution volume adopted for this test was 1:5. The solution containers were kept at room temperature, and the solution was stirred regularly, at least twice in a day to maintain uniformity. The solution was replaced at regular intervals to maintain the concentration of solution throughout the test period. The tests were conducted after $30 \mathrm{~min}, 6 \mathrm{~h}, 24 \mathrm{~h}, 48 \mathrm{~h}$, and $72 \mathrm{~h}$ from the date of immersion. After removing the specimens from the solution, the surfaces were cleaned with a soft nylon wire brush under the running tap water to remove weak reduction products and loose material, the testing of specimens under acid attack test as shown in fig 3.2

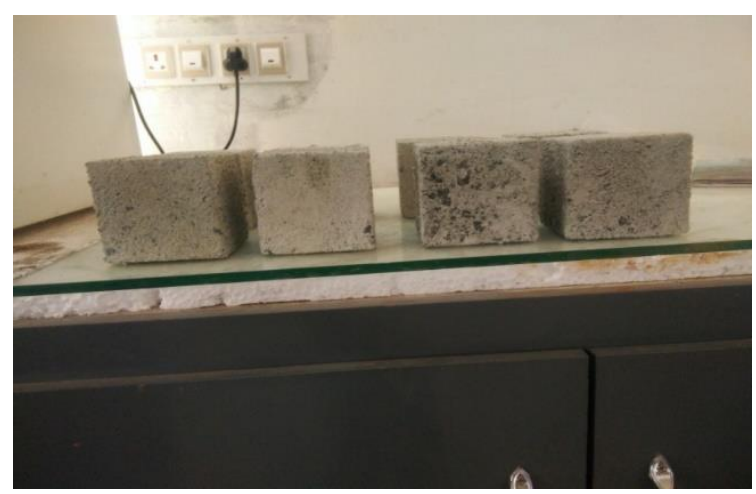

Fig.3.2 Acid attack test for concrete

The results of the parameter studied as weight loss for all concretes were presented in Table 3.3 and 3.4. It can be seen that RHA concretes showed lower weight loss compared to normal concrete, but at lower strengths, the variations in weight loss between these concretes were only marginal. At higher strengths, the RHA concretes performed better compared to normal concretes. In general, it can be seen that weight loss was decreasing with increasing percentage replacement.

Table 3.3 Effect of acid attack on concrete investigated

\begin{tabular}{|c|c|c|c|}
\hline \multicolumn{4}{|c|}{ Age of Testing ( 28 days ) } \\
\hline S.NO & Name & $\begin{array}{c}\text { Charge } \\
\text { Passed } \\
\text { (Coulombs } \\
\text { ) }\end{array}$ & $\begin{array}{c}\text { Type of } \\
\text { concrete }\end{array}$ \\
\hline 1 & C0 & 780 & Very Low \\
\hline 2 & C5 & 950.8 & Very Low \\
\hline 3 & C10 & 1290.7 & Low \\
\hline 4 & C15 & 2109 & Moderate \\
\hline
\end{tabular}


Table 3.4 Rapid chloride ion penetration test results

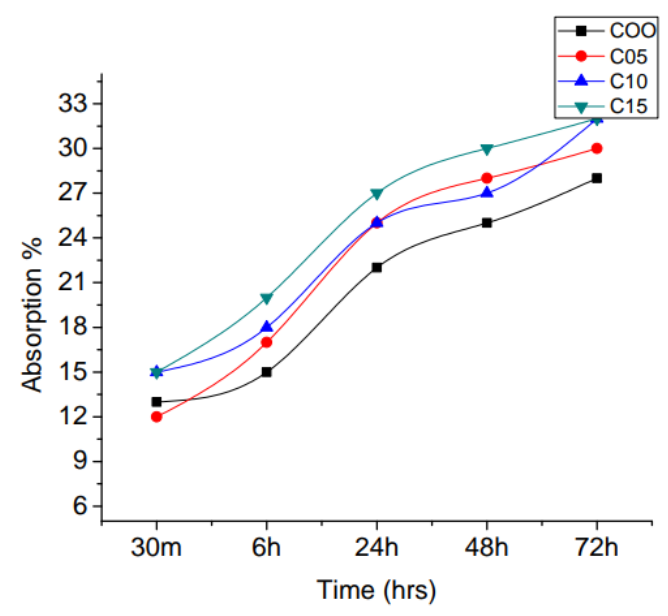

Fig 3.3 Water absorption test results

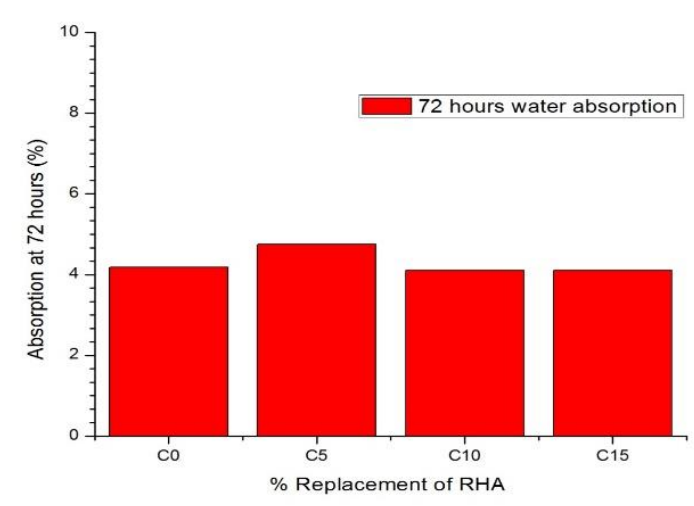

Fig 5.3 Water absorption @ 72 hours

\subsection{Compressive strength test results}

The compressive quality of concrete for various replacements of cement with $5 \backslash \%, 10 \backslash \%$ and $15 \backslash \%$ of RHA and $100 \backslash \%$ M-Sand were tried for 7,28 and 56 days utilizing compressive test machine. The water cement ratio was taken as 0.30 .from the Figure 4.5 it has been seen that, the comparison of Compressive strength results of concrete for various replacements of cement with RHA and 100\\% M-Sand At 10\\% replacement of RHA and $100 \backslash \%$ M-Sand gives maximum 28 days compressive strength $87.03 \mathrm{~N} / \mathrm{mm}^{2}$

\section{CONCLUSIONS}

1. The experimental investigations on RHA concretes, designed with the proposed mix design method using these efficiencies, show that concretes of very high strengths (around 90MPa) could be produced with reasonable ease. It was observed that at a replacement of about $10 \%$ the maximum strength of about $90 \mathrm{MPa}$ can be obtained. The limitation on maximum replacement percentages possible for a particular strength was also established.

2. According to the assessment criteria of the Concrete Society (CEB, 1989). Similar trend was also seen in the case of the other related parameters like absorption, evaporation and moisture migration.

3. The deterioration characteristics of these concretes, assessed in $5 \% \mathrm{H}_{2} \mathrm{SO}_{4}$, show that weight loss was decreasing with increasing RHA percentage replacement. In particular, RHA concretes performed better than normal concrete.

4. The RHA concretes showed higher resistance to chloride ion diffusion compared to normal concretes and the resistance increased with increasing strength and all levels of replacements. All the RHA concretes were assessed as very low chloride permeability concretes as per ASTM C1202-94 assessment criteria. The total charge passing, typically for the $10 \%$ replacement concretes, was in the range of 400 to 600 coulombs for RHA concretes compared to the range of 1000 to 3000 coulombs for normal concretes.

\section{ACKNOWLEDGEMENT}

We sincerely thanks to our chairman Sri. M Prabhakar Reddy GARU for fostering an excellent academic environment and labs during our project work.

We sincerely thank Dr. B.D. Venkatramana Reddy M.Tech., Ph.D., and Director of our college for his suggestions during our project work.

We sincerely thank Dr. V. Senthil Murugan M.E, Ph.D., and principal of our college for fostering an 
excellent academic environment and for his suggestions during our project work.

We are grateful to Mr. R. Surya Prakash M.E, Head of the Department for his support guidance, valuable suggestions, and uninterrupted cooperation during our project work.

\section{REFERENCES}

[1]. ASTM C 452, "Test Method for Potential Expansion of Portland Cement Mortars Exposed to Sulphates", Annual Book of ASTM Standards, V 4.01, (1989), pp. 225-227.

[2]. ASTM C 642, "Test Method for Specific gravity, Absorption and Voids in Hardened Concrete", Annual Book of ASTM Standards, V 4.02, pp. 310-313.

[3]. ASTM C1202-94, "Standard Test Method for Electrical Induction of Concrete's Ability to Resist Chloride Ion Penetration", Annual Book of ASTM Standard, V 4.02, (1995), pp.624-629.

[4]. ACI Committee 211.1, "Standard Practice for Selecting proportions for Normal, Heavy weight and Mass Concrete”, (1991).

[5]. Boateng A. A. and Skeete D. A, "Incineration of Rice Hull for use as a Cementitious Material: The Guyana Experience", Cement and Concrete Research, Vol. 20, (1990), pp. 795-802.

\section{Cite this article as :}

S. Swarna Manjula, R. Surya Prakash, "A Study on Differential Characteristics of HSC Containing RHA and M-Sand as an Aggressive Environment", International Journal of Scientific Research in Science and Technology (IJSRST), Online ISSN : 2395-602X, Print ISSN : 2395-6011, Volume 8 Issue 6, pp. 365-371, November-December 2021. Available at doi : https://doi.org/10.32628/IJSRST218648 Journal URL : https://ijsrst.com/IJSRST218648 